2020:5(6):199-206

http://ojs.uho.ac.id/index.php/JIA

doi: http://dx.doi.org/10.37149/JIA.v5i6.14994

\title{
PENINGKATAN PRODUKTIVITAS DENGAN RELAYOUT AREA PRODUKSI DI UKM KERIPIK TEMPE (Studi Kasus di UKM Suka Nicky, Banjarnegara)
}

\author{
Hety Handayani Hidayat ${ }^{\left.{ }^{*}\right)}$, Nur Wijayanti ${ }^{1)}$, Arif Prasetyo ${ }^{1)}$ \\ ${ }^{1}$ Jenderal Soedirman University \\ *Corresponding author : hety.hidayat@unsoed.ac.id
}

To cite this article:

Hidayat, H., Wijayanti, N., \& Prasetyo, A. (2020). Peningkatan Produktivitas dengan Relayout Area Produksi di UKM Keripik Tempe (Studi Kasus di UKM Suka Nicky, Banjarnegara). JIA (Jurnal Ilmiah Agribisnis) : Jurnal Agribisnis dan IImu Sosial Ekonomi Pertanian, 5(6), 199 - 206. doi:http://dx.doi.org/10.37149/jia.v5i6.14994

Received: November 09, 2020; Accepted: December 19, 2020; Published: December 31, 2020

\section{ABSTRACT}

SMEs are required to continue to make continuous improvements to increase productivity. One alternative that can be done is to re-layout the facilities and production areas. The main purpose of this research is to identify an increase in productivity with the proposed re-layout. Layout planning is carried out using the ARC (Activity Relations Chart) approach, the area requirements of each production facility, and the limitations of SMEs. From the results of the research conducted from January until March 2020, it is known that the proposed re-layout can improve material handling efficiency in Suka Nicky. Originally 219.75 meters which were taken in 148.5 minutes turned into 194.65 meters with a time of 117.5 minutes. With the decrease in distance and material handling time, the hope is that it can reduce the operational costs of SMEs.

Keywords: activity relationship chart; efficiency; re-layout

\section{PENDAHULUAN}

Produktivitas merupakan salah satu alternatif strategi bagi industri untuk meningkatkan keuntungan karena dapat mengontrol dan menghemat biaya operasional (Gunasekaran et al., 1996; Ongkorahardjo, 2015) Demikian halnya dengan UKM Suka Nicky, yang memproduksi berbagai macam makanan ringan dengan keripik tempe sebagai komoditas utamanya. Menurut keripik tempe ini telah menjadi produk ungulan oleh-oleh dari area Banjarnegara, Purbalingga, Banyumas, Cilacap, dan Kebumen (Wijayanti, Hidayat, Pertanian, et al., 2019) Oleh karena itu, maka persaingan industri produk ini sangatlah kompetitif sehingga UKM perlu melakukan perbaikan terus menerus untuk meningkatkan produktivitasnya.

Produktivitas UKM dituntut meliputi efisiensi penggunaan sumber daya input, efektivitas dalam pencapaian tujuan, dan kemampuan memenuhi persyaratan kualitas yang diinginkan konsumen (Pristiana et al., 2015). Salah satu upaya peningkatan produktivitas khususnya dalam aspek efisiensi tersebut adalah dengan melakukan serangkian proses perbaikan tata letak stasiun kerja dalam proses produksinya (Iskandar \& Fahin, 2017). Secara spesifik, perancangan ulang tata letak ini juga merupakan upaya mewujudkan lean manufacturing dengan menimasi pergerakan baik barang maupun karyawan (Fitriyani et al., 2019). Pergerakan dikategorikan sebagai pemborosan (waste) sebagai kegiatan tidak penting untuk produksi (Narusawa \& Shook, 2009). Proses meminimasi waste yang terdapat dalam proses produksi bertujuan meperlancar proses produksi (Maulana et al., 2013).Dibandingkan dengan memekanisasi beberapa stasiun kerja, perubahan layout proses produksi lebih memungkinkan untuk diterapkan oleh UKM dengan segala keterbatasan termasuk UKM Suka Nicky. Mekanisasi memerlukan investasi yang cukup besar, sedangkan perubahan layout ini dapat memaksimalkan kondisi yang ada.

Lebih lanjut dituturkan oleh Islam et al., (2017) bahwa layout yang baik diperlukan untuk menghilangkan pemborosan berupa waktu dan tenaga dalam material handling selama proses produksi serta mencegah terjadinya cross contamination (kontaminasi silang) terhadap produk. Hal ini diperkuat oleh Nuha et al., (2019) yang menunjukkan bahwa dengan melakukan perubahan layout 
pada proses produksi pengecoran logam di CV Mandiri Jaya Logam dapat memperlancar proses produksi, mempermudah pemilahan bahan baku dan meningkatkan keteraturan dan kerapihan area. Penataan ulang layout dengan memperhatikan keterkaitan hubungan antar kegiatan juga telah berhasil meningkatkan $61,68 \%$ produktivitas di UD. Supra Dinasty Denpasar yang merupakan UKM produsen bakso ayam (Al Haq et al., 2015). Lebih jauh dipaparkan oleh Kitriastika et al. (2013) dalam penelitiannya mampu menurunkan angka lead time sebesar $34,82 \%$ pada simulasi dengan layout pasca perbaikan. Bahkan dalam industri besarpun perubahan layout ini dapat meningkatkan profitabilitas. Seperti halnya yang diungkapkan Iskandar dan Fahin (2017) dalam penelitiannya di PT Mercedes Benz Indonesia khususnya pada proses produksi Truck di Gedung Commercial Vechical (CV) dapat menurunkan biaya material handling sebanyak lebih dari Rp 15.000,00 per hari. Demikian halnya dengan Purnomo et al. (2013) yang mengurangi hampir 100 meter perpindahan jarak dari hasil perancangan layoutnya pada proses produksi Ribbed Smoked Sheet (RSS) di Jember. Penelitian serupa juga dilakukan oleh Kumar et al. (2016) yang melakukan simulasi terhadap perubahan tata letak fasilitas di salah satu UKM di Malaysia sehingga diperoleh scenario yang mengahasilkan peningkatan produktivitas sebesar $37,5 \%$.

Meskipun berdasarkan hasil-hasil penelitian terdahulu tersebut menunjukkan keberhasilan peningkatan produktivitas namun untuk melakukan perubahan di UKM tidaklah mudah. Hal ini memerlukan perancangan yang sesuai dengan memperhatikan keterbatasan yang spesifik di setiap UKM. Oleh karena itu penelitian ini dilakukan untuk menganalisis peningkatan produktivitas di UKM Suka Nicky dengan melakukan perancangan ulang tata letak sesuai dengan kondisi dan keterkaitan kegiatan yang ada.

\section{MATERI DAN METODE}

Penelitian ini dilakukan di UKM Suka Nicky yang beralamat di Desa Gumiwang, Kecamatan Purwanegara, Kabupaten Banjarnegara pada Bulan Januari hingga Agustus 2020. Tahapan yang dilakukan pada penelitian ini sebagai berikut:

1. Observasi dilapangan untuk mengetahui alur proses produksi keripik tempe serta tata letak awal di UKM suka Nicky.

2. Melakukan perancangan ulang tata letak

Perancangan dildasarkan pada hubungan keterkaitan antara suatu kegiatan dengan kegiatan lainnya dalam Peta Keterkaitan Kegiatan (ARC). Kegiatan yang dianggap penting akan selalu diutamakan untuk berdekatan. Tujuannya agar menjamin kelancaran aktivitas proses produksi. Adapun dalam pengsisianya melibatkan warna ataupun symbol hurup dan dan angka. Warna dan arti yang terkandung dalam ARC adalah sebagai berikut: merah menyatakan hubungan mutlak (A), kuning pekat beraarti keterkaitan sangat penting (E), hijau bermakna penting (I), kuning menggambarkan biasa $(\mathrm{O})$, putih menunjukkan tidak diinginkan $(\mathrm{U})$, dan biru bermakna tidak penting. Sedangkan bagian bawah diisi dengan alas an keterkaitan tersebut yaitu : 1) menyatakan adanya aliran informasi, 2) bahwa kegiatan tersebut memiliki derajat pengawasan, 3) berhubungan karena adanya urutan aliran kerja, 4) terdapat aliran material, 5) berfungsi saling menunjang, 6) menyatakan tidak berhubungan, 7) adanya fasilitas saling terkait, 8) bising, kotor, bau, debu dan 9) safety (Rosyidi, 2018). Selain pemetaan keterkaitan kegiatan, dalam perancangan tata letak usulan juga dilakukan perhitungan luas area yang dibutuhkan, perancangan layout dengan memperhatikan keterbatasan UKM.

3. Analisis peningkatan produktivitas. Pengukuran Produktivitas dilakukan berdasarkan perhitungan ukuran jarak/panjang lintasan dan waktu kerja perpindahan material pada layout baru/usulan.

\section{HASIL DAN PEMBAHASAN}

\section{Tata Letak Keripik Tempe UKM suka Nicky (Kondisi Awal)}

UKM Suka Nicky memproduksi dua varian keripik tempe yakni keripik tempe mocaf dan keripik tempe balutan (biasa). Perbedaan keduanya adalah pada saat pembuatan tempe, untuk keripik tempe mocaf, mocaf dicampurkan pada sebelum fermentasi kedelai serta tidak dilakukan pembalutan bumbu tepung saat penggorengan(Afriyanti, 2017). Namun dalam penelitian ini berfokus pada proses produksi keripik tempe balutan atau biasa. Dimana tempe dibuat dengan cara mencuci hingga menyelip kedelai, merebus kedelai, kemudian dibungkus dan difermantasi, dipotong, dicelupkan bumbu tepung saat penggoregan pertama, dilakukan penggorengan kedua, ditiriskan dan dikemas (Nurani \& Kurniati, 2019; Trianasari et al., 2017). Keripik tempe balutan ini dipilih karena menjadi komoditas utama di UKM ini dengan kapasitas produksi rata-rata mencapai $116 \mathrm{~kg}$ per hari. 
Gambar 1 berikut merupakan layout produksi keripik tempe di UKM Suka Nicky. Layout tersebut menggambarkan terdapat 15 stasiun kerja pada proses produksi dengan 1 area kebun dan kolam.

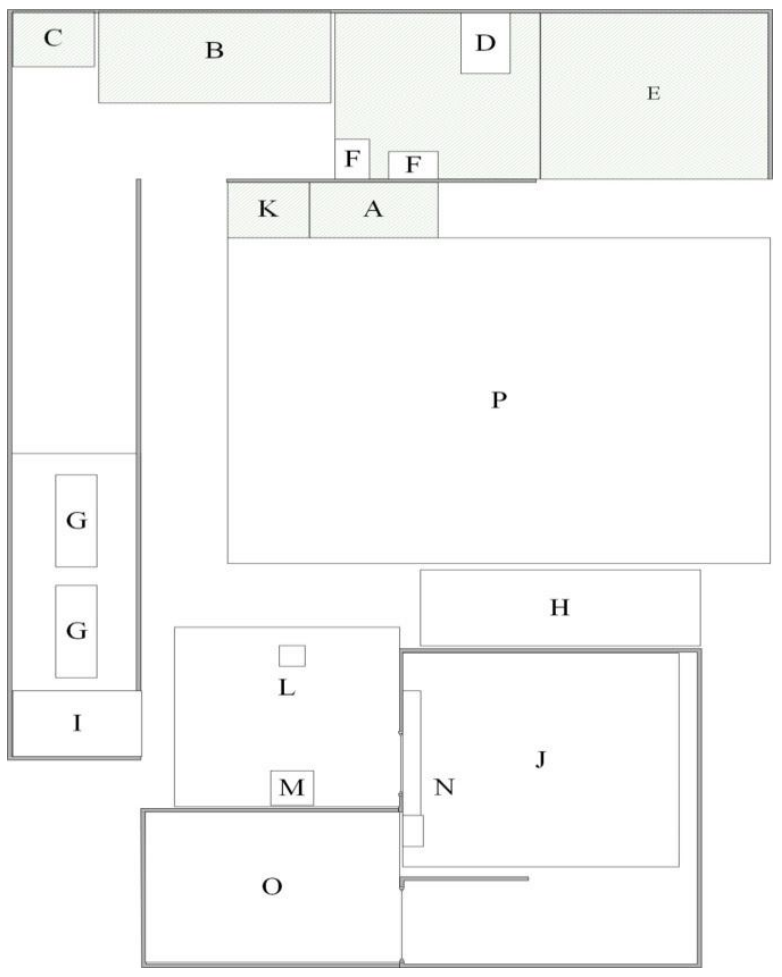

Keterangan :

A. Gudang Bahan Baku 1

B. Area Pencucian, Perendaman, dan Penyelipan Kedelai

C. Area Perebusan Kedelai

D. Area Pembungkusan Tempe

E. Ruangan Fermentasi

F. Area Pemotongan Tempe

G. Area Penggorengan Tahap 1

H. Gudang Bahan Baku 2

I. Area Pembuatan Bumbu

J. Dapur dan Ruangan Penyimpanan Sementara

K. Blender dan Penumbukan Garam

L. Area Penggorengan Tahap 2

M. Area Penirisan Keripik Tempe

N. Area Pengemasan

O. Ruangan Penjualan

P. Kebun dan Kolam Ikan

Gambar 1. Layout produksi keripik tempe Suka Nicky

Setelah mengetahui tata letak awal, dilakukan identifikasi aliran material yang terjadi agar dapat mengambarkan permasalahan, jarak dan waktu perpindahan saat ini(Naganingrum et al., 2013). Semua perpindahan material dilakukan dengan secara manual yakni diangkut oleh karyawan (Mas'idah et al., 2009). Selain faktor jarak, jumlah material yang dipindahkan juga perlu diperhatikan karena terdapat keterbatasan karyawan dalam memindahkan material (Affa \& Putra, 2017). Misalnya pemindahan kedelai ke perebusan, karyawan hanya mampu mengangkut $25 \mathrm{~kg}$ sekali jalan. Dengan demikian untuk mengangkut $75 \mathrm{~kg}$ dilakukan sebanyak 3 kali sehingga memerlukan waktu yang lebih lama. Secara lebih terperinci jarak perpindahan material di area produksi dapat dilihat pada Tabel 1. Data pada tabel 1 ini merupakan rata-rata nilai yang diperoleh selama observasi dan pengukuran langsung di lapangan.

Tabel 1. Jarak dan waktu perpindahan material area produksi pada layout awal

\begin{tabular}{cccc}
\hline Dari & Ke & $\begin{array}{c}\text { Jarak } \\
(\mathrm{m})\end{array}$ & $\begin{array}{c}\text { Waktu } \\
(\text { menit })\end{array}$ \\
\hline A & B & 5 & 1,25 \\
B & C & 3 & 0,75 \\
B & D & 7,5 & 1 \\
C & B & 3 & 0,75 \\
D & E & 6 & 28 \\
E & F & 6 & 7 \\
F & G & 20 & 46 \\
G & L & 6 & 19 \\
H & I & 10 & 8 \\
I & G & 12 & 28 \\
J & K & 27 & 6 \\
K & I & 17 & 4 \\
L & M & 3 & 12 \\
M & N & 2 & 9 \\
N & O & 21 & 49 \\
\hline Total & & 148,5 & 219,75 \\
\hline
\end{tabular}


Jenis material dan perpindahan alur material serta jumlahnya yang digunakan per hari dalam proses produksi keripik tempe terdapat pada Tabel 2.

Tabel 2. From to chart

\begin{tabular}{lcc}
\hline \multicolumn{1}{c}{ Material } & Jumlah rata-rata/hari & $\begin{array}{c}\text { Urutan Proses } \\
\text { (sesuai stasiun kerja) }\end{array}$ \\
\hline Kedelai & $75 \mathrm{~kg}$ & A-B-C-B-D-E \\
Tempe & 92 wadah & E-F-G \\
Tepung terigu & $45 \mathrm{~kg}$ & H-I-G \\
Tepung Mocaf & $4 \mathrm{~kg}$ & H-I-G \\
Tepung Tapioka & $22 \mathrm{~kg}$ & H-I-G \\
Bumbu dapur & $3,5 \mathrm{~kg}$ & J-K-I-G \\
Keripik tempe & $116 \mathrm{~kg}$ & G-L-M-N-O \\
\hline
\end{tabular}

\section{Perancangan ulang (relayout) tata letak area produksi keripik tempe}

Perancangan ulang tata letak di UKM Suka Nicky dilakukan dengan pendekatan Peta Keterkaitan Aktivitas/Analisis Activity Relation Chart (ARC). Selain hasil observasi, ARC pada Gambar 2 ini juga disusun berdasrkan hasil diskusi dengan pemilik UKM. Dengan melihat ARC ini dapat diketahui peluang-peluang aktivitas mana yang dapat dipindahkan untuk mendekati akticitas lain yang berhubungan erat dan terjadi aliran material.

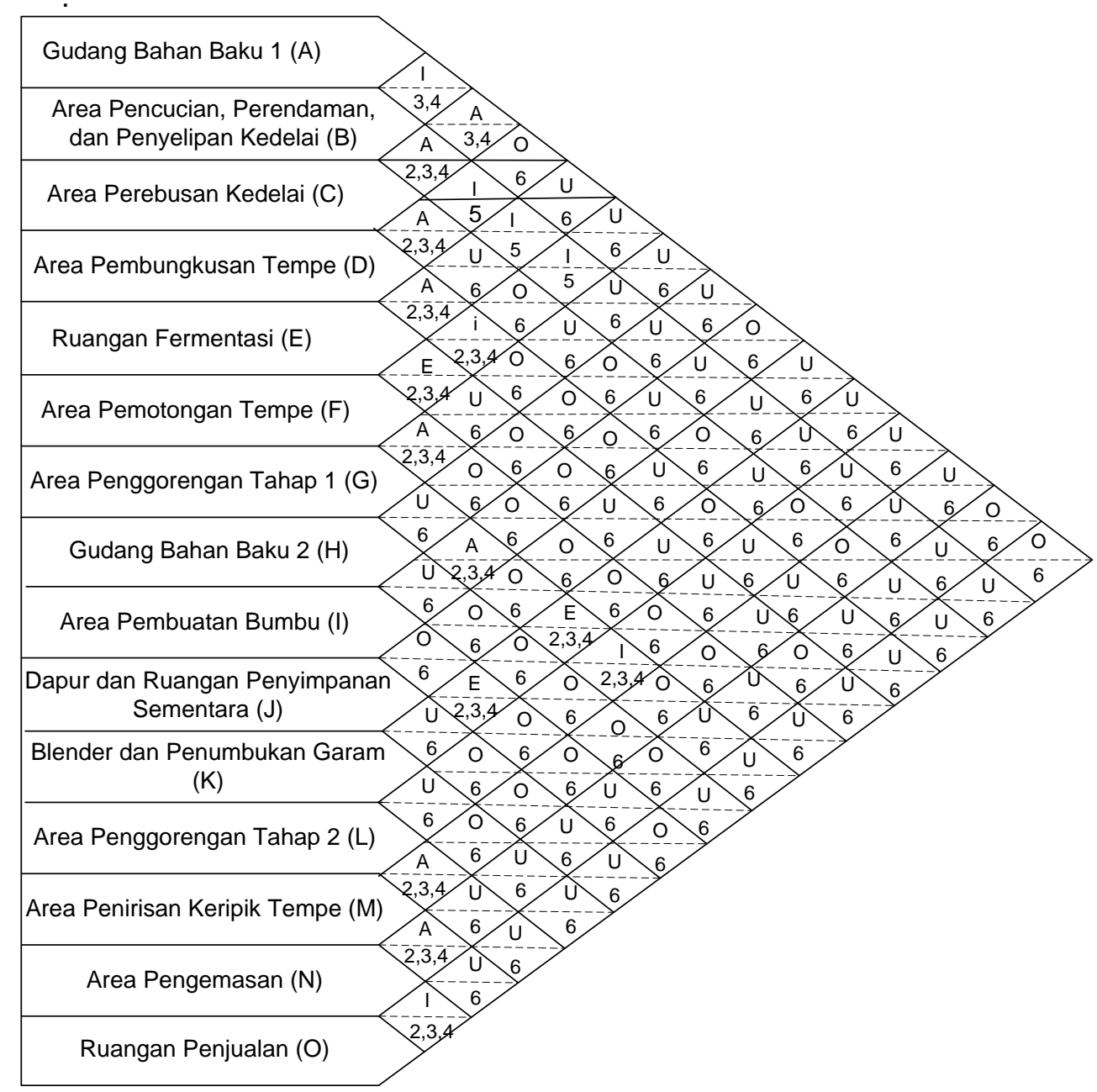

Gambar 2.Diagram keterkaitan kegiatan / Activity Relation Chart (ARC)

Setelah mengetahui hubungan antar aktivitas, maka data lain yang diperlukan dalam perancangan layout baru adalah mengetahui luas area yang diperlukan untuk masing-masing kegiatan tersebut. Dengan melakukan pengukuran langsung terhadap alat atau fasilitas serta kebutuhan area maka diperoleh data tersebut yang ditabulasikan pada Tabel 3 berikut ini. 
Tabel 3. Total luas area yang dibutuhkan

\begin{tabular}{|c|c|c|}
\hline & Kode Stasiun Kerja/Departemen & $\begin{array}{l}\text { Luas area } \\
\left(\mathrm{m}^{2}\right)\end{array}$ \\
\hline A. & Gudang Bahan Baku 1 & 5,4 \\
\hline B. & Area Pencucian, Perendaman, dan Penyelipan Kedelai & 13,75 \\
\hline C. & Area Perebusan Kedelai & 3,06 \\
\hline D. & Area Pembungkusan Tempe & 2,16 \\
\hline $\mathrm{E}$. & Ruangan Fermentasi & 25,92 \\
\hline $\mathrm{F}$. & Area Pemotongan Tempe & 2,16 \\
\hline G. & Area Penggorengan Tahap 1 & 5,4 \\
\hline $\mathrm{H}$. & Gudang Bahan Baku 2 & 14,08 \\
\hline I. & Area Pembuatan Bumbu & 6 \\
\hline J. & Dapur dan Ruangan Penyimpanan Sementara & 42,78 \\
\hline $\mathrm{K}$. & Blender dan Penumbukan Garam & 3,6 \\
\hline L. & Area Penggorengan Tahap 2 & 0,36 \\
\hline M. & Area Penirisan Keripik Tempe & 1 \\
\hline N. & Area Pengemasan & 1,94 \\
\hline \multirow[t]{2}{*}{ O. } & Ruangan Penjualan & 27 \\
\hline & Total & 154,61 \\
\hline
\end{tabular}

Selain memperhatikan luas area yang diperlukan dan keterkaitan antar kegiatan, perubahaan layout juga memperhatikan keterbatasan yang ada. Keterbatasan tersebut meliputi:

1. Area pencucian, perendaman dan penyelipan Kedelai tidak dapat dipindahkan karena di area ini terdapat sumur sebagai sumber air. Jika area dipindahkan maka memerlukan tambahan instalasi air dan listrik. Penambahan instalasi ini akan meningkatkan biaya kontruksi dimana hal ini tidak sesuai deangan tujuan desain tata letak yakni meminimalkan biaya konstruksi, baiaya perpindahan dan biaya produksi atau penyimpanan (Sofyan \& Syarifuddin, 2018).

2. Seperti halnya pada UKM keripik tempe lainnya, UKM Suka Nicky juga pada tahap penggorengan 1 masih menggunakan tunggu konvensional dengan kayu bakar sebagai bahan bakarnya (Mustiadi et al., 2019; Wijayanti, Hidayat, \& Satriani, 2019). Tungku ini terbuat dari batu bata yang ditanam, sehingga pemindahan area ini sangat sulit dilakukan oleh UKM Suka Nicky.

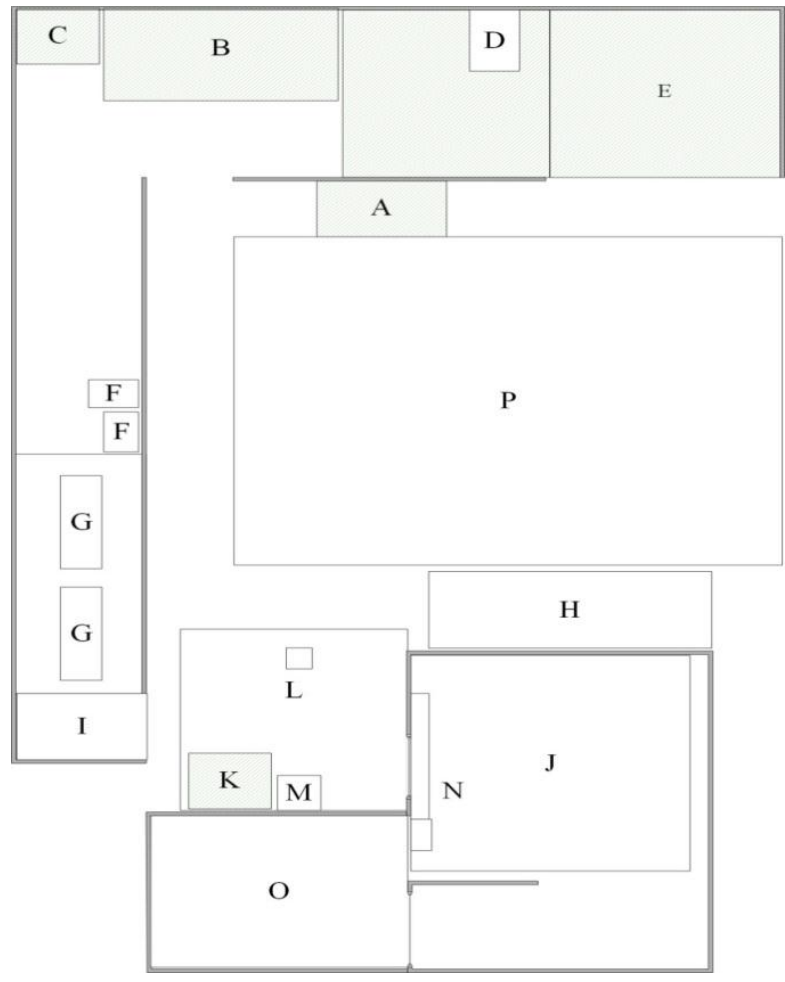

Keterangan :

A. Gudang Bahan Baku 1

B. Area Pencucian, Perendaman, dan Penyelipan Kedelai

C. Area Perebusan Kedelai

D. Area Pembungkusan Tempe

E. Ruangan Fermentasi

F. Area Pemotongan Tempe

G. Area Penggorengan Tahap 1

$\mathrm{H}$. Gudang Bahan Baku 2

I. Area Pembuatan Bumbu

J. Dapur dan Ruangan Penyimpanan Sementara

K. Blender dan Penumbukan Garam

L. Area Penggorengan Tahap 2

M. Area Penirisan Keripik Tempe

N. Area Pengemasan

O. Ruangan Penjualan

P. Kebun dan Kolam Ikan

Gambar 3.Layout setelah perbaikan 
Berdasarkan pertimbangan tersebut maka hasil layout yang direkomendasikan dapat dilihat pada Gambar 3 di atas. Adapun perbedaan perubahan yang diusulkan meliputi:

1. Pemindahaan statsiun kerja pemotongan tempe (F) untuk dipindahkan mendekati area penggorengan tahap 1. Pemindahan ini dilakukan karena dari stasiun pemotongan terjadi aliran bahan berupa potongan tempe dengan frekuensi yang sering ke area penggorenagan. Hal ini sesuai dengan penelitian Rosyidi (2018) bahwa aliran bahan menjadi faktor yang sangat penting dalam mendesain ulang tata letak.

2. Stasiun kerja (K) dipindahkan mendekati area pembuatan bumbu (I) karena area yang masih memungkinakan serta mengurangi mobilitas karyawan.

\section{Perbandingan Produktivitas Tata Letak Awal dan Relayout}

Pergerakan (motion) berupa perpindahan material dan tenaga kerja yang berlebihan merupakan salah satu pemborosan dengan frekuensi cukup sering terjadi di industri sehingga sangat perlu untuk diminimasi (Liker, 2006; Soenaryo et al., 2015). Oleh karena itu, tujuan relayout adalah meminimasi perpidahan material yang terjadi. Dengan adanya perbaikan ini diharapkan dapat meringankan pekerja sehingga dapat menekan jumlah pekerja yang dibutuhkan. pekerja dapat bekerja lebih efisien yang akan memperbaiki kinerja UKM (Tabassum \& Khan, 2016). Perbaikan kinerja tersebut meliputi peningkatan produktivitas. Hal ini selaras dengan Kovács dan Kot (2017) yang menyatakan bahwa perancangan layout yang tepat dapat secara siginifikan meningkatkan efisiensi dalam lini produksi serta menurunkan biaya.

Tabel 4. Perbandingan Jarak dan Waktu Antar Stasiun Kerja yang lama dan baru

\begin{tabular}{ccrrrr}
\hline Dari & Ke & $\begin{array}{c}\text { Layout Kondisi Awal } \\
\text { Jarak }\end{array}$ & $\begin{array}{c}\text { Waktu } \\
\text { (menit) }\end{array}$ & $\begin{array}{c}\text { Jarak } \\
\text { (meter) }\end{array}$ & $\begin{array}{r}\text { Waktu } \\
\text { (menit) }\end{array}$ \\
\cline { 3 - 6 } & B & 5 & 1,25 & 5 & 1,25 \\
B & C & 3 & 0,75 & 3 & 0,75 \\
B & D & 7,5 & 1 & 7,5 & 1 \\
C & B & 3 & 0,75 & 3 & 0,75 \\
D & E & 6 & 28 & 6 & 28 \\
E & F & 6 & 7 & 23 & 28 \\
F & G & 20 & 46 & 3 & 7 \\
G & L & 6 & 19 & 6 & 19 \\
H & I & 10 & 8 & 10 & 8 \\
I & G & 12 & 28 & 12 & 28 \\
J & K & 27 & 6 & 10 & 2,2 \\
K & I & 17 & 4 & 3 & 0,7 \\
L & M & 3 & 12 & 3 & 12 \\
M & N & 2 & 9 & 2 & 9 \\
N & O & 21 & 49 & 21 & 49 \\
\hline Total & & 148,5 & 219,75 & 117,5 & 194,65 \\
\hline
\end{tabular}

Tabel 4 diatas menunjukkan dengan adanya relayout pada UKM Suka Nicky maka terjadi perubahan jarak material handling pada proses produksi keripik tempe. Jarak material flow pada UKM Suka Nicky semula 219,75 meter yang ditempuh dalam waktu 148,5 menit. Setrelah dilakukan perancangan ulang tata letak fasilitas jarak berubah menjadi 194,65 meter dengan waktu selama 117,5 menit. Hal ini selaras dengan hasil penelitian Purnomo et al., (2013) yang juga telag berhasil menurunkan jarak perpindahan material pasca perbaikan tata letak. Dengan kata lain maka relyout telah berhasil mengurangi biaya pemindahan bahan sebagai salah satu dari tujuan utama relayout yakni minimasi biaya kontruksi, perpindahan material dan biaya produksi maupun penyimpanan(Sofyan \& Syarifuddin, 2018).

\section{KESIMPULAN DAN SARAN}

Rancangan ulang tata letak fasilitas produksi keripik tempe di UKM Suka Nicky dilakukan dengan memperhatikan keterkaitan antar kegiatan dan keterbatasn UKM. Dengan menerapkan layout yang baru, UKM dapat meningkatkan produktivitas tepatnya peningkatan efisiensi material handling sebesar $14,11 \%$. Efisiensi tersebut berupa penurunan waktu perpindahan material sebanyak 21,5 menit atau 31 meter per hari produksi. 


\section{UCAPAN TERIMA KASIH}

Terima kasih kepada LPPM Universitas Jenderal Soedirman atas pemberian dana penelitian BLU skim Riset Dosen Pemula Tahun Anggaran 2020 serta UKM Suka Nicky telah membantu dan berpartisisi aktif dalam pelaksaan penelitian

\section{REFERENSI}

Affa, M. N., \& Putra, B. I. (2017). Analisis Manual Material Handling Pada Pekerja Borongan Di PT. JC dengan Metode NBM dan RWL. Prozima (Productivity, Optimization and Manufacturing System Engineering), 1(1), 22. https://doi.org/10.21070/prozima.v1i1.703

Afriyanti, A. (2017). Pendugaan Umur Simpan Keripik Tempe Sagu Menggunakan Pengemas Plastik PP dengan Metode Arrhenius. Jurnal IImu Pangan Dan Hasil Pertanian, 1(1), 72. https://doi.org/10.26877/jiphp.v1i1.1353

Al Haq, Z., Semadi Antara, N., \& Hartiati, A. (2015). Perancangan Tata Letak Ulang (Relayout) Pabrik Terhadap Tingkat Produksi Produk Bakso Ayam (Studi Kasus Pada Pabrik Bakso UD. Supra Dinasty Denpasar). Jurnal Rekayasa Dan Manajemen Agroindustri, 3(2), 80-91.

Fitriyani, R., Saifudin, S., \& Margareta, K. (2019). Usulan Perbaikan untuk Pengurangan Waste Pada Proses Produksi dengan Metoda Lean Manufacturing. Jurnal PASTI, 13(2), 187. https://doi.org/10.22441/pasti.2019.v13i2.008

Gunasekaran, A., Okko, P., Martikainen, T., \& Yli-Olli, P. (1996). Improving Productivity and Quality in SMEs: Cases and Analysis. In International Small Business Journal.

Iskandar, N. Mu., \& Fahin, I. saffrina. (2017). Perancangan Tata Letak Fasilitas Ulang (Relayout) untuk Produksi Truk di Gedung Commercial vechicle (CV) PT. Mercedes-Benz Indonesia. PASTI, XI(1), 66-75.

Islam, M. A., Rashed, C. A. A., \& Hasan, J. (2017). Productivity Improvement Through the Application of Systematic Layout Planning. Review of General Management, 25(1), 38-54.

Kitriastika, V., Tanaya, P. I., \& Indrayadi, Y. (2013). A Redesign Layout to Inctrease Productivity of A Company. Jurnal Ilmiah Teknik Industri, March, 83-95.

Kovács, G., \& Kot, S. (2017). Facility layout redesign for efficiency improvement and cost reduction. Journal of Applied Mathematics and Computational Mechanics, 16(1), 63-74. https://doi.org/10.17512/jamcm.2017.1.06

Kumar, V., Verma, P., Onkar, Singh, S. P., \& Katiyar, J. (2016). Facility and process layout analysis of an SME using simulation: A case study of a manufacturing company. Proceedings of the International Conference on Industrial Engineering and Operations Management, 8-10 March(March), 1294-1304.

Liker, J. K. (2006). The Toyota Way: 14 Prinsip Manajemen dari Perusahaan Manufaktur Terhebat di Dunia. Erlangga.

Mas'idah, E., Fatmawati, W., \& Ajibta, L. (2009). Analisa Manual Material Handling (Mmh) Dengan Menggunakan Metode Biomekanika Untuk Mengidentifikasi Resiko Cidera Tulang Belakang (Musculoskeletal Disorder) (Studi Kasus pada Buruh Pengangkat Beras di Pasar Jebor Demak). Sultan Agung, XLV(119), 37-56.

Maulana, A., Herlina, L., \& Kurniawan, B. (2013). Usulan Lean Manufacturing System untuk Mereduksi Waste Dan Efisiensi Biaya Produksi Di PT . ABC Divisi Slab Steel Plant 1. 2-9.

Mustiadi, L., Astuti, S., \& Rastini, F. E. K. (2019). Penerapan Teknologi "Tuyuheji" Pada Industri Tempe Sebagai Upaya Peningkatan Produktivitas Dan Pendapatan UKM. Jurnal Aplikasi Dan Inovasi Ipteks SOLIDITAS, 2, 50-58.

Naganingrum, R. P., Jauhari, W. A., \& Herdiman, L. (2013). Perancangan Ulang Tata Letak Fasilitas di PT. Dwi Komala dengan Metode Systematic Layout Planning. Performa, 12(1), 39-50.

Narusawa, T., \& Shook, J. (2009). Kaizen Express: Fundamental for Your Lean Journey. Lean Enterprise Institute.

Nuha, H., Saves, F., \& Murnawan, H. (2019). Penataan Ulang Tata Letak (Relayout) Fasilitas Produksi. 111-118.

Nurani, F. P., \& Kurniati, E. (2019). Penyuluhan Sistem Keamanan Pangan Dalam Produksi Keripik Tempe Di Desa Parerejo Kabupaten Jawa Timur. Jati Emas (Jurnal Aplikasi Teknik Dan Pengabdian Masyarakat), 3(1), 104. https://doi.org/10.36339/je.v3i1.195

Ongkorahardjo, E. P. (2015). Formulasi Strategi Usaha Makanan Ringan. Agora, 3(2), 665-674.

Pristiana, U., Hidayati, C., \& Wiwoho, B. (2015). Peningkatan Produktivitas Dan Profitabilitas Bagi Ukm Sentra Industri Kue Bakpia Di Gempol Pasuruan Jawa Timur. Jurnal Pengabdian LPPM Untag Surabaya Nopember, 01(02), 147-152. 
Purnomo, B. H., Rusdianto, A. S., \& Hamdani, M. (2013). Desain tata letak fasilitas produksi pada pengolahan ribbed smoked sheet (RSS) di Gunung Pasang Panti Kabupaten Jember. Jurnal Agroteknologi, 7(2), 167-177. https://jurnal.unej.ac.id/index.php/JAGT/article/view/2272

Rosyidi, M. R. (2018). Analisa tata letak fasilitas produksi dengan metode ARC, ARD, dan AAD di PT. XYZ. Jurnal Teknik Industri, 16(1), 82-95.

Soenaryo, H., Rispianda, \& Yuniati, Y. (2015). Usulan Meminimasi Waste Pada Proses Produksi Dengan Konsep Lean Manufacturing di CV. X. Jurnal Online Institut Teknologi Nasional, 3(2), 92-103.

Sofyan, D. K., \& Syarifuddin, S. (2018). Perancangan Ulang Tata Letak Fasilitas Dengan Menggunakan Metode Konvensional Berbasis 5S (Seiri, Seiton, Seiso, Seiketsu Dan Shitsuke). Jurnal Teknovasi: Jurnal Teknik Dan Inovasi, 2(2), 27-41. https://ejurnal.plm.ac.id/index.php/Teknovasi/article/view/58

Tabassum, Z., \& Khan, A. (2016). Production Line Analysis via Value Stream Mapping: A Case Study in Pakistani. International Journal of Innovative Research in Science, Engineering and Technology, 5(12), 172-178.

Trianasari, E., Pamuji, D. R., Prayogo, G. S., \& Rahayu, N. S. (2017). Pemanfaatan Teknologi Tepat Guna Mesin Pengiris Tempe Untuk Meningkatkan Produktifitas Umkm Keripik Tempe Di Desa Siliragung Kecamatan Siliragung. 10(November), 64-66.

Wijayanti, N., Hidayat, H. H., Pertanian, F., \& Soedirman, U. J. (2019). Analisis faktor kansei konsumen terhadap kemasan keripik tempe cokelat. 3(November), 282-290.

Wijayanti, N., Hidayat, H. H., \& Satriani, R. (2019). Peningkatan Kualitas Produk melalui Renovasi Dapur Produksi dan Pelatihan Pengemasan pada IKM Keripik Tempe. Pengembangan Sumber Daya Perdesaan Dan Kearifan Lokal Berkelanjutan IX, 304-310. 